\title{
Poetic song of Hester. Secondary infertility: Losing infants, INHERITING A CHILD
}

\author{
Authors: \\ Ilse Gravett ${ }^{1}$ \\ Julian C. Müller

\begin{abstract}
Affiliations:
${ }^{1}$ Department of Practical

Theology, University of
\end{abstract} \\ Pretoria, South Africa \\ Correspondence to: \\ Ilse Gravett \\ email: \\ ilsegrav@mweb.co.za

\section{Postal address:} \\ Department of Practical \\ Theology, Faculty of \\ Theology, University of \\ Pretoria, Lynnwood Road, \\ Hatfield 0083, Pretoria, \\ South Africa
}

\section{Keywords:}

African feminist theology; infertility within the African context; issues of death; mutual embracement; secondary infertility

\section{Dates:}

Received: 04 Nov. 2009

Accepted: 12 Apr. 2010

Published: 08 Sept. 2010

How to cite this article: Gravett, I. \& Müller, J.C., 2010, 'Poetic song of Hester. Secondary infertility: Losing infants, inheriting a child' HTS Teologiese Studies/ Theological Studies 66(2), Art. \#844, 5 pages. DOI: 10.4102/hts.v66i2.844

\section{This article is available}

at:

http://www.hts.org.za

\section{Note:}

This article is a reworked version of a section from Ilse Gravett's PhD dissertation,

'Narratives of couples affected by infertility: Daring to be fruitful', with Prof. Dr Julian C. Müller as supervisor. The dissertation was submitted and accepted by the Faculty of Theology of the University of Pretoria in August 2008.

(C) 2010. The Authors. Licensee: OpenJournals Publishing. This work is licensed under the Creative Commons Attribution License.

\section{ABSTRACT}

The aim of the article was to explore the narrative of Hester, a black South African woman, who is living with secondary infertility. The perspective is that of postfoundational practical theology, feminist theology and social constructionist narrative methodology. Fertility, as one of the most intimate areas of human existence, lies at the heart of life itself. Within the African tradition, motherhood is seen as almost sacred. Despite Hester's multiple identities, one which is that of adoptive mother, the absence of biological children causes her to be regarded as a 'childless' woman. That identity not only disproportionately defines her, but also stigmatises her as shameful and an outsider. Within the traditional African worldview being healthy (including being fertile) is seen as being in harmony with the societal order and systemic, spiritual and religious environment.

Hester's social construction of her 'self' is that of helplessness, reflected in her near illiteracy, low economic status, socio-cultural position and lack of skills. Her childlessness reinforced her helplessness. Her 'woundedness' was perpetuated by the fact that she could not share her painful story openly. In the article Hester's story is presented as a poem, titled: 'the thing that doesn't want to come out'. The article concludes with Hester's reconstruction of 'self' as a woman, although poor, also blessed.

\section{INTRODUCTION}

\section{A poem on infertility}

Hester's story of her 'childlessness' was told during three interviews, with Hester's adopted daughter, Florence, taking part in the last one. The term 'childless' is ironic, since Hester had given birth to twins and has an adopted daughter. However, she does not have a living biological child and is therefore not regarded as a 'real' mother by her community. The conversations were transcribed from audiotape. The 60 pages of verbatim text were then condensed into a four-and-a-half page poem. I adopted social scientist Laurel Richardson's (1992:126) idea of presenting her interview with someone called Louisa May in the form of a poem. Richardson had a number of reasons for choosing the poetic form. Firstly, she wanted something other than the dull academic style of paraphrasing case studies or simply quoting interviewees directly. Secondly, she argued that, by allowing Louisa's language to shape the poem, she decentred herself as the 'expert sociologist' and reached a sensitive, ethical solution to the issues of 'authority/authorship/ appropriation' whereby she felt she could use her 'skills and resources in the service of others less beneficially situated' (Richardson 1992:131). It was inevitable that she did interpret Louisa May's words, life and experiences, but, presenting them in a certain pattern that meticulously reflected the speaker's tone, diction and meaning and using only Louisa May's words, she tried to do so with subjective integrity. Thirdly, Richardson liked the idea of finding a union between the sociological and the poetic, because this is an important part of how she prefers to express herself as a sociologist and an individual. What she found, in the end, was that, in writing about Louisa May, she also rewrote her own self. Coming from a narrative point of departure, I could identify with Richardson's thinking and, in telling Hester and Florence's story, I was inspired to make use of poetic representation in a similar way.

The poem uses Hester and Florence's own words. The nature and mood was conveyed by making use of poetic devices such as repetition, pauses, foregrounding of words and emotions, 'free verse' and dramatic progression. The fact that poetry by nature lends itself to multiple and open readings in greater measure than does conventional prose or traditional narrative research writing, influenced my decision to tell Hester and Florence's story in the form of a poem. Todorov (1981) describes the aim of poetic representation as an attempt to 'name the text that was examined' (or, in this instance, to name the conversation with Hester and Florence). The act of 'naming' reflects the determination to make the text itself speak:

It is a fidelity to the object, to the other, and consequently an effacement of the subject - as well as its drama, which is to be forever incapable of realising the meaning, but only a meaning, subject to historical and psychological contingencies.

(Todorov 1981:4)

In this article, the following issues will be considered in the course of Hester's narrative: infertility in the African context, secondary infertility, Hester's poem, Hester imagining Hannah in the temple and Hester reconstructing her 'self'.

\section{BACKGROUND}

The story of Hester and Florence, mother and adopted daughter, was originally told as part of the $\mathrm{PhD}$ thesis, 'Narratives of couples affected by infertility: Daring to be fruitful'. As one of four very different stories told by four different couples on the issue of infertility, Hester gives her voice to the painful experience of stigmatisation and marginalisation that often shapes the lives of the childless living in the context of the African tradition. 
The voices of Black women, such as Hester, have historically and culturally been silenced. Black women from non-developed countries are often disadvantaged in a threefold way: by racism, sexism and class differences (Bons-Storm 1992:134). Within the social constructionist view, the 'self' is constituted in relationship with other persons (Freedman \& Combs 1996:268). Since infertility in the African tradition is a highly uncomfortable topic, childless men and women often encounter a deafening silence even within the church, which echoes the cruel, hushed stigmatisation they face in their communities. By discussing the theme of infertility, it is not only the couple and their intimate life that is made public, but their parents' personhood is also compromised, and that is unacceptable (Gabobonwe 2004:67).

Hester's 'self' is also constituted in relationship to her inherited child and adopted daughter, Florence. Although they love and respect each other as parent and child, some members of their community continuously remind them that they are not 'really' (biologically) mother and daughter and that their bond is of inferior quality.

The aim of the article is that the voices of Hester and Florence be heard. In African culture there is generally not much sympathy for childless couples. Antagonism is especially directed at the woman who is seen as the cause of the infertility problem.

\section{EPISTEMOLOGY AND METHODOLOGY}

This article is written from of a post foundational, social constructionist narrative perspective. It endorses an emancipatory feminist objective.

According to South African feminist theologian, Denise Ackermann (1998:80), a hermeneutic of healing should be at the heart of a feminist theology of praxis. Meaningful healing resists the pursuit of only individual and personal healing and rather recognises the interlocking of social, political and religious forces and the challenge to bring healing to people's lives on multiple levels.

If African theology is about reflecting on how Christians in Africa understand God, then women's theology ensures the inclusion of women's expression of faith in response to their experiences. The main thrust of women's theology is to make a concerted effort to open the door for the voices of 'men and women, lay and ordained, teachers and preachers, poets and sculptors'. Secondly, this theology takes life as a whole into consideration, everything that constitutes fullness of life - wellbeing, the possession of powers, attributes and abilities that lead to a celebration of life (Oduyoye 2001:34).

The 'Circle of Concerned African Women Theologians' (also known as the Circle), was initiated in 1989 by Mercy Amba Oduyoye to encourage gender-sensitive research and writing on African religions and culture by women. It also created a supportive space for African feminist theologians to develop creative practical theologies that grew out of their specific experiences and needs. Oduyoye, guilty of the ultimate failure of childlessness, raises her voice as an African theologian in the Circle to propose a theology of procreation that responds to the challenge and disgrace of barrenness. She laments the fact that Christianity apparently lacks stories from which the childless can draw strength (Oduyoye 1999:115). Another possibility is that stories that do exist are purposely ignored or are undeveloped because the church fails to appreciate the diverse ways in which men and women can live fruitful lives despite childlessness. She puts it as follows: 'It is for the church to acknowledge and raise up the diversity of God's gifts and to celebrate all the ways of bringing forth life' (Oduyoye 1999:119). Such a theology of procreation speaks to both those who reproduce and those who do not. Such a theology is gracious and mature enough to embrace different forms of fruitfulness, which might not necessarily be biological. It is a theology that teaches the church and traditional culture to understand and respect the unique 'state of life' of the childless, that refuses to further blame and shame those who are infertile.

\section{HESTER'S HELPLESSNESS}

Hester's helplessness manifests in her near illiteracy, low economic status, lack of any skills other than domestic capabilities, but mostly in her not being the biological mother of children Two husbands had left her. Her first husband took another wife, because Hester had failed to fall pregnant again after they had lost their twins. The second husband left her after a 17-year marriage, because she never conceived and could not give him children.

None of the ex-husbands was available to take part in this research. Therefore I invited Florence, Hester's adopted daughter and her granddaughter, Thandi, to participate.

\section{THE STORY BEHIND THE POEM}

Hester is a 45-year-old Tswana woman. She comes from a closeknit family of seven children. Hester and one of her sisters, Rosie, are childless.

At the age of 19 , she gave birth to twins. Although they were born prematurely at 7 months, they were sent home shortly after birth. The girl was called Nyane, meaning 'small' and the boy was called Moss, short for Moses. The 'tiny one' died when she was only a week old and Moss passed away when he was 9 months old.

On every Good Friday for the last 27 years, Hester and her mother visit the babies' graves. She assures her deceased babies that she still loves them very much and that her heart has broken many times over.

Seven years after the death of her twins and while she was married to Samuel, her second husband, another tragedy struck the family. One day, her brother Piet had an argument with his wife because, as usual, she had used their food money to gamble at the casino. He was so angry that he hit her on the head with a brick. Bleeding and unconscious, she fell to the ground. Fearing the consequences of what he had done, Piet ran away and hanged himself in a room in his parents' house. The family discovered the dead woman in her house, the daughter, Florence, trying to drink from her dead mother's breast. Florence's younger brother was asleep in the next room. The tragedy offered a single compensation: Hester and Rosie, the two childless sisters, now inherited a child each. Hester got the 9-month-old Florence, and Rosie got her 2-year-old brother.

Florence, the inherited daughter, the substitute child, once again made Hester into a mother and Florence, the orphan, found in Hester a replacement for the mother she had lost. They love each other, but theirs is a bittersweet union. Members of the community continually remind them that they are not 'really' mother and daughter and that their relationship is second best. 'Your parents are dead', they would say to Florence. 'You can't have children', they would accuse Hester. 'So you are not a mother and child', they conclude firmly.

In Hester's narrative, there is an undercurrent of unspeakable grief and hurt that she articulates as being pregnant with a 'heaviness of pain and sadness', a 'something that doesn't want to come out'. It never releases its grip on her heart and it waits for her at the break of every day. 'The thing that doesn't want to come out' keeps her in a pregnant state of such pain that she is always close to tears. Part of her wounded state is that she cannot share her painful story openly in her community, and find understanding, care and empathy. Alone, she bears in her body the infection of childlessness, like a decomposed infant. 


\section{HESTER'S POEM}

'The thing that doesn't want to come out'

in Rooifontein my house stands empty

dirty alone

nobody there to care for

only me eating my money

even if your little house is nice

it's a trouble to be without a child

my heart is very sore

very sore

it makes me scream inside

sometimes $i$ cry - oo hoooo -

like a wolf

poor me

gaana ngwana

$i^{\prime} m$ a poor woman

(my mother's heart also cries with me

my father always says why why?)

when $i$ was nineteen the twins came too early

$i$ took them home to Hammanskraal

Nyane lived one week

she was very cold in the morning

he got to nine months Moss i loved him

from then on this thing is heavy

this thing

this thing that doesn't want to come out

it is big trouble

it talks to me every day

it holds me dead tight

what shall $i$ say?

we must have children

we must

it's just how it is

the morena was good

he gave

Florence to me

when she was a small mosetsanyana

a bad thing happened

her ma and pa had a fight

killed each other over the devil money

her pa said where's the money?

the casino swallowed it!

her ma said

she fell

he didn't mean to hit her that hard

hanged himself with the rope then

my empty sesi Rosie

she got the little moshimanyana

we were so happy

now we had children

we didn't sign the adoption papers

always we cry together

about the children

we hold each other

why our young sesie Willemina has four children

why?

and she's the youngest of all of us

we always cry me and Rosie

the sangoma threw the bones

if it sits like this it means so

if it sits like that it means so

she said the time is not right

the muti is working

$i$ must wait six months

the baby will come

but it didn't help

she took my money

Samuel said i must sleep with his brother

to make a new child but no i didn't want to

it's better this way

$i$ didn't like that man

the family wasn't angry

you don't have to really

this world is not a place to stay in

it is too hard for me

Samuel left me

we were together seventeen years

'uh huh you can't make children'

he left me

it wasn't right to run off

just like that

why must he go away after he promised me

where can i run to?

it's a lot of trouble this thing

the morena knows some can have children

some not

we pray in the church holding hands in the air going up and up

you have you have you have not

you have not you have you have not

you have not

we think maybe if we say something else

the morena will give

the others throw their children away

at the river

yes they put them

in the dustbin

and the toilet did you know the toilet

$i$ think who is going to look after me

when i'm old?

the others don't want me to send their child

to the shop

to make the tea

they say $i$ must do it myself

$i$ think many stories

$i$ must buy the baby at the hospital

they have the ones there

without mothers

(i'm laughing at myself now

but my heart stays

sore)

every day $i$ ask the morena

all day every day

why don't you give me one?

only one

please

$i^{\prime} m$ asking you for one only

$i$ can't hear him

$i$ don't know why

the morena speaks to me but $i$ don't understand

$i^{\prime}$ 'm old now

it's

too late

i mustn't feel like this

my heart pulls me down

grabs me

like a fist

it's not only me

too many women without children

all of us are pushed outside in this world

it doesn't help to cry every day

what will i do to become strong?

$i$ have Florence

she's my daughter

$i$ have Florence

she's my daughter

she wants to be a nurse

but she didn't get matric

when her baby came we called her Thandi 
Florence is crying because the father left her

married someone else but he is still

the neighbour

she sees them together

he and the other woman

she cries a lot

Thandi cries too

that other woman swears at them

Thandi's nose is small

like her father's

Hester is my mother I love her too much

she taught me to cook

I'm shy and big boned

I like to smile

my mother makes us chicken and pap

we are good friends

she helps me

$i$ want to get a job

I didn't like school

the easy maths told me not to take all the money

for the clothes in Truworths

I must go back to school

but now it is difficult

I want

more babies

Florence is my daughter

i love her

and Thandi

these ones are my little children

there's this thing in me that does not want to

come out

Florence is my daughter

$i$ love her and Thandi and Moss and Nyane

these ones are my little children

there's this heavy thing that i carry inside

it makes me pregnant

with rivers of crying

from that time it speaks to me every day

my heart is very

very sick

i pray that god will take it away from me

will you pray with me that he will make me to get strong?

this world is full of trouble

(i can't help crying)

\section{SECONDARY INFERTILITY}

Although the poem presents a number of themes, this article will focus on dominant discourses such as secondary infertility and infertility in the African tradition.

Secondary infertility is described as the inability to conceive a pregnancy or carry a pregnancy to term following the birth of one or more children' (Simons 1995:2). It means that a woman has had at least one live child. Secondary infertility occurs among individuals and couples who previously had little or no problem in conceiving, as well as among those with recurring infertility difficulties. It is regarded not only as a medical diagnosis, but also as a social and emotional crisis

Although it is even more common than primary infertility, it is a hidden form of infertility, an unfamiliar loss, and communities lack proper language to give adequate support. Unused to addressing such a difficult loss with acknowledgments, ceremonies, rituals and understanding, society prefers to ignore it (Simons 1995:13). Hester's poem reflects her pain and confusion in terms of secondary infertility.

\section{INFERTILITY IN THE AFRICAN CONTEXT}

When referring to the 'African' context one should take care to keep 'the rich diversity of modes of being in Africa' in mind and not fall into the trap of thinking of Africa as a homogeneous society. The word 'Africa' points to 'a philosophical concept that describes the complexity and diversity of different cultural, local and contextual settings as related to a state of being and mind (Louw 2007:13). Africa also embodies the 'spirit' or soul of its people's humanness and refers to a hermeneutical paradigm that differs from the analytical approach stemming from Hellenism and Western thinking.

As far as the African individual is concerned, being healthy means being in the right relationship with the environment. It signifies that the societal order and systemic, spiritual and religious equilibrium are in harmony. Illness (including infertility) in this context is both a sociological phenomenon (as it affects the whole community) and a religious concept (Louw 2007:25).

Berinyuu (cited in Louw 2007:26) points out that illness immediately provokes suspicion of what sin the person has committed in order to incur the current misfortune or death. Illness is seen not as the result of viruses or infections in the body but as the result of someone having disturbed the social order. Infertility in the traditional African context is not ascribed to 'purely medical reasons' or 'unexplained causes'. It reflects directly on a person who has done something wrong. The community finds that it has the right to scrutinise such people's lives and hold them responsible.

In most parts of Africa motherhood is seen as almost sacred, 'a religious duty' and a way to prove you are a full and faithful person' (Oduyoye 1999:113). As if the pain of being childless were not enough, the state of infertility in itself is a curse which alienates people from community life. It is believed not only to affect the infertile person but blights the entire community, thereby undermining the survival of the clan and preventing ancestors from being born again into earthly life (Mathekga 2001:37). A woman's body is, inter alia, seen as a vehicle for the reincarnation of her ancestors (Oduyoye 1999:105).

An infertile family member causes disharmony which affects the family also in the future. Living in abundance and fullness in this life means that a good life can be expected also in the afterlife. In some cultures, the eternal life is traditionally viewed as an endless continuation of the person's family line. The ability to have children then takes on religious significance. Because the Bible speaks of children as a gift from God, the community assumes the opposite also to be true: childlessness demonstrates the curse of the Lord on the couple. Even a husband and wife with strong Christian beliefs might become bitter and angry towards God because they are influenced by the community's interpretation of their situation (O'Donovan 1996:296).

In a study on the views of Black South Africans (Mabasa 2000:62), it was found that infertility was seen as a severe stigma. The general belief was that infertility is more common in women than men and, in fact, should be seen as a women's problem. The thinking in the African culture is that as long as a man is potent, he cannot be sterile. The comparison is made between a woman taking in the seed that grows to be a baby and the fertile soil that germinates the seed of maize and develops root. Traditional healers would often confirm that the infertility problem lies with the woman. In African patrilineal society, infertility is seen to be the woman's fault and is thus not a problem of the couple (Mathekga 2001:37).

\section{HESTER IMAGINING HANNAH} IN THE TEMPLE

Mercy Oduyoye (1999:118) explains how her liberation from the label of useless, shameful woman, which she received from her church and the African community, took place while she was visiting the island of Crete. She (once again) prayed to God, as Hannah did in the temple, to allow her to 'join in the command to increase and multiply', when he dealt with her directly: and 'God was saying a clear no to my offer'. But it was not the kind of 
refusal that indicated she was not worthy of becoming a mother. Her acceptance of God's answer through God's grace allowed her to feel free and fertile, sure that something precious would be born of this experience. She laid her life on the altar before God to consume what was not necessary for her journey, she says. Then she arose, like Hannah, and although the promise to her did not include a child, she was nonetheless 'pregnant with the expectation of great things to come to me from God' (Oduyoye 1999:118). She realised that children are God's gift to creatures who need to survive through procreation. However, in Oduyoye's life the command to procreate means the following:

\section{Increase in humanity.}

Multiply the likeness to God for which you have the potential.

Multiply the fullness of humanity that is found in Christ.

Fill the earth with the glory of God.

Increase in creativity.

Bring into being that which God can look upon and pronounce 'good', even 'very good'

(Oduyoye 1999:118)

In Hester's case, she habitually looks for care and sanctuary amongst her church community. The pastor sometimes meets with those women of his flock who have reproductive difficulties and together they pray and seek solace from God. Hester often used to pray in church and beg God to grant her at least one child. Like Hannah in the temple, she speaks from her own painful experience of loss and despair.

In the familiar temple scene, Hannah (the gracious one) rose and prayed silently before the Lord, with only her lips moving. She vowed that if she were to give birth to a son she would dedicate him to the Lord's service. Lacking insight, Eli accused her of making a drunken spectacle of herself. But Hannah assured him that, because of her great complaint and bitter provocation, she was pouring out her soul before the Lord: 'I am a woman of sorrowful spirit' (1 Sm 1:15), she said.

Leila Berner (2000:37) describes Hannah's prayer as the first instance of 'personal prayer' in the Jewish tradition. Eli found this direct and intimate form of religious devotion so unusual that he mistook her pleading for intoxication. Berner points out that communication with God is motivated by different social conditions and the scope for religious expression should be broadened. She proposes that the 'normative' tradition should be evaluated and reflected upon. Its language should be flexible enough to be redefined and reconstituted to become relevant to both male and female perceptions of reality, and both male and female experiences of spirituality and religious life (2000:42).

Hannah set an example by speaking to God in her own way. She expressed herself to God by pouring out her heart and defended herself boldly against Eli. In her beautiful thanksgiving psalm for her son, Hannah declares: 'My heart exalts ... my mouth is no longer silent, for it is opened widely before my enemies, because I rejoice in your salvation' (1 Sm 2:1).

\section{CONCLUSION}

'Hester as the Other, different, shunned to the periphery, existing on the margins of power'. That, of Hester's many identities, is prominent in the context of her story as the mother of an adopted daughter. She is the Other amongst those who have the ability to procreate. Especially within the African tradition, she is reminded of her incapacity by the unfair naming of her humanness in terms of a devalued identity. She is the Other also in terms of her own bodily self. In Serene Jones's words, 'the self is figured as having thwarted agency - thwarted capacity for self-creation. While the self may still possess the body, the body refuses to yield what the self desires' (2001:237). Her body denies her its natural inclination to bring forth new life; it declines to answer her call for motherhood and is experienced as a place where death dwells. She desperately wants to leave the barren desert behind, but, alas, she lives in the desert; she is the desert. In addition, she experiences herself as the Other who fell out of favour in the religious circle of God's presence, believing her unanswered prayers for 'only one child' proved Divine disregard.

Hester reconstructed her 'self' by concluding that she is both a poor woman because of her losses and a blessed woman because she received children through other women, Florence from her sister-in-law and Thandi, her granddaughter from Florence. She holds onto her faith for dear life, but cannot understand why God does not reverse her fate, or why he allowed the babies to leave her in the first place.

\section{REFERENCES}

Ackermann, D., 1998, "'A voice was heard in Ramah": A feminist theology of praxis for healing in South Africa', in D. Ackermann \& R. Bons-Storm (eds.), Liberating faith practices: Feminist practical theologies in context, pp. 75-102, Peeters, Leuven.

Berner, L.G., 2000, 'Hearing Hannah's voice: The Jewish feminist challenge and ritual innovation', in Y. Yazbeck Haddad \& J.L. Esposito (eds.), Daughters of Abraham: Feminist thought in Judaism, Christianity, and Islam, pp. 35-49, University Press of Florida, Gainesville, FL.

Bons-Storm, R., 1992, Pastoraat als bondgenootschap: Aanzet tot vernieuwing van de kerkelijke praktijk vanuit het vrouwenpastoraat [Chaplaincy as an alliance: Towards the renewal of religious practice from the women's ministry], Kok, Kampen.

Farley, M.A. \& Jones, S. (eds.), 1999, Liberating eschatology: Essays in honor of Letty M. Russell, Westminster John Knox, Louisville, KY.

Freedman, J. \& Combs, G., 1996, Narrative therapy: The social construction of preferred realities, WW Norton, NY.

Gabobonwe, O.H., 2004, 'Barrenness in marriage: A challenge to pastoral Care', unpublished MA dissertation, University of Pretoria.

Jones, L.S., 2001, 'Hope deferred: Theological reflections on reproductive loss (infertility, miscarriage, stillbirth)', Modern Theology 17(2), 227-245.

Louw, D., 2007, 'Spirituality and healing in "soul care": Towards a comprehensive understanding of human wholeness within a contextual and "African paradigm"', paper presented at Pretoria Academic Hospital, Pretoria.

Mabasa, L.F., 2000, 'Stigma, community support and therapy methods of infertility in South Africa: A cultural perspective', Psychotherapy and African Reality 62-73.

Mathekga, H.L., 2001, 'The psychosocial implications of infertility on African couples', unpublished MA (Social Work) dissertation, University of Pretoria.

O'Donovan, W., 1996, Biblical Christianity in African perspective, Paternoster Press, Carlisle.

Oduyoye, M.A., 1999, 'A coming home to myself', in M.A. Farley \& S. Jones (eds.), Liberating eschatology: Essays in honor of Letty M. Russell, pp. 105-120, Westminster John Knox, Louisville, KY.

Oduyoye, M.A., 2001, Introducing African women's theology, Sheffield Academic Press, Sheffield.

Richardson, L., 1992, 'The consequences of poetic representation: Writing the other, rewriting the self', in C. Ellis \& M.G. Flaherty (eds.), Investigating subjectivity: Research on lived experience, pp. 125-137, Sage Publications, Newbury Park, CA.

Simons H.F., 1995, Wanting another child: Coping with secondary infertility, Lexington Books, NY.

Todorov, T., 1981, Introduction to poetics: Theory and history of literature, vol. 1, University of Minnesota Press, Minneapolis, $\mathrm{MN}$.

Villa-Vicencio, C. \& De Gruchy, J.W. (eds.), 1994, Doing ethics in context: South African perspectives, Orbis Books, Maryknoll, NY.

Yazbeck Haddad, Y. \& Esposito, J.L. (eds.), 2002, Daughters of Abraham: Feminist thought in Judaism, Christianity, and Islam, University Press of Florida, Gainesville, FL. 